\title{
Upstream structural management measures for an urban area flooding in Turkey
}

\author{
Z. Akyurek ${ }^{1}$, B. Bozoğlu ${ }^{1}$, S. Sürer ${ }^{2}$, and H. Mumcu ${ }^{3}$ \\ ${ }^{1}$ METU, Civil Eng. Dept. Water Resources Lab, Ankara, Turkey \\ ${ }^{2}$ DHI-TURKEY, Ankara, Turkey \\ ${ }^{3}$ Hydraulic Works, Samsun Regional Office, Samsun, Turkey \\ Correspondence to: Z. Akyurek (zakyurek@metu.edu.tr)
}

Received: 11 March 2015 - Accepted: 11 March 2015 - Published: 11 June 2015

\begin{abstract}
In recent years, flooding has become an increasing concern across many parts of the world of both the general public and their governments. The climate change inducing more intense rainfall events occurring in short period of time lead flooding in rural and urban areas. In this study the flood modelling in an urbanized area, namely Samsun-Terme in Blacksea region of Turkey is performed. MIKE21 with flexible grid is used in 2-dimensional shallow water flow modelling. $1 \times 1000^{-1}$ scaled maps with the buildings for the urbanized area and $1 \times 5000^{-1}$ scaled maps for the rural parts are used to obtain DTM needed in the flood modelling. The bathymetry of the river is obtained from additional surveys. The main river passing through the urbanized area has a capacity of $500 \mathrm{~m}^{3} \mathrm{~s}^{-1}$ according to the design discharge obtained by simple ungauged discharge estimation depending on catchment area only. The upstream structural base precautions against flooding are modelled. The effect of four main upstream catchments on the flooding in the downstream urban area are modelled as different scenarios. It is observed that if the flow from the upstream catchments can be retarded through a detention pond constructed in one of the upstream catchments, estimated $Q_{100}$ flood can be conveyed by the river without overtopping from the river channel. The operation of the upstream detention ponds and the scenarios to convey $Q_{500}$ without causing flooding are also presented. Structural management measures to address changes in flood characteristics in water management planning are discussed.
\end{abstract}

\section{Introduction}

Flooding has the potential to cause significant impacts to economic activities as well as to disrupt or displace populations. Changing climate regimes such as extreme precipitation events increase flood vulnerability and put additional stresses on infrastructure. Knowing that flood risk is a function of flood vulnerability and flood hazard, the studies performed so far for obtaining flood hazard maps depend on the numerical solution of shallow depth flow equations using DEM, cross-sections along the channel and the discharges having different return periods obtained from meteorological forcing. The hydrodynamic modelling approach is considered to be the most suitable method for generating comprehensive flood hazard maps at high spatial and temporal resolutions. The hydrodynamic modelling approach is used to simulate flood inundation in floodplains using both onedimensional and two-dimensional modelling schemes. Especially for urban floods, the upstream and/or downstream precautions must be clarified to decrease the floods' adverse effects.

The flood problem is not a recent issue neither for Turkey nor for other countries. Therefore, the need for the flood protection and flood management are not new too. There are many studies about flood management around the world. Recent researches suggest a risk-based approach in flood management (Hooijer et al., 2004; Petrow et al., 2006; van Alphen and van Beek, 2006). The necessity to move towards a risk based approach has also been recognized by the European Parliament (de Moel et al., 2009), which adopted a new Flood Directive (2007/60/EC) on 23 October 2007. According to the EU Flood Directive, the member states must 
Table 1. The peak values of the hydrographs having different return period for four subbasins and the area of the sub basins.

\begin{tabular}{lllllllll}
\hline & Area $\left(\mathrm{km}^{2}\right)$ & $Q_{2}$ & $Q_{5}$ & $Q_{10}$ & $Q_{25}$ & $Q_{50}$ & $Q_{100}$ & $Q_{500}$ \\
\hline 2245 & 232.8 & 219.71 & 350.43 & 446.74 & 578.27 & 682.83 & 792.41 & 1041.34 \\
Basin1 & 75.14 & 70.92 & 113.11 & 144.19 & 186.64 & 220.39 & 255.76 & 336.11 \\
Basin 2 & 46.66 & 44.04 & 70.24 & 89.54 & 115.90 & 136.86 & 158.82 & 208.71 \\
Basin 3 & 109.96 & 103.78 & 165.52 & 211.01 & 273.14 & 322.53 & 374.28 & 491.86 \\
Basin 4 & 134.88 & 127.30 & 203.03 & 258.83 & 335.04 & 395.62 & 459.11 & 603.33 \\
\hline
\end{tabular}

prepare the flood hazard and risk maps for their territory and then these maps will be used for flood risk management plans. Structural management measures play also important role among various mitigation facilities and flood management strategies.

Various flood mitigation facilities were constructed and some flood management strategies were established in Turkey following the severe floods; some of which are 2526 August 1982 (Ankara), 18-20 June 1990 (Trabzon), 1617 May 1991 (Eastern Anatolia), 4 November 1995 (İzmir), 21 May 1998 (Western Black Sea), 28 May 1998 (Hatay), 2 November 2006 (Batman), and 9 October 2011 (Antalya) (Şahin, 2013).

The aim of this study is to analyse the possible upstream structural measures for an urban area flooding. The effect of meanders to the flood peak discharge attenuation at the downstream part of the stream was also analysed.

\section{Study area and data}

Study area is selected from Black Sea region of Turkey. The mean rainfall is $720 \mathrm{~mm}$ per year and the topography is tough due to the mountains lying parallel to the sea and they cause flash floods in the urban areas located on the coast line. The Terme River passes through Terme city centre and separates city into two parts. The project area is beginning from the Black Sea and going through $32 \mathrm{~km}$ upstream of Terme. First $6 \mathrm{~km}$ of the study area is settlement area of city. The Terme River and upstream part with four branches contribute the study area. In July 2012 Terme City Centre was exposed a small flood event. Approximately $510 \mathrm{~m}^{3} \mathrm{~s}^{-1}$ flood discharge passed through the city. The river water level reached top of the levees and some parts were over flowed.

$1 \times 5000^{-1}$ scaled orthophotos for the upstream part of the urbanized area, $1 \times 1000^{-1}$ scaled point elevation data for the urbanized area and the river bathymetry measurements were used to obtain the digital elevation model (DEM) of the area. The study area is depicted in Fig. 1a. The study is performed for the area between the upper catchments and Terme Bridge. Since detailed flood hazard mapping for the urban area, Terme, was available, therefore the hydrographs observed from the flood modelling were used in the comparison.
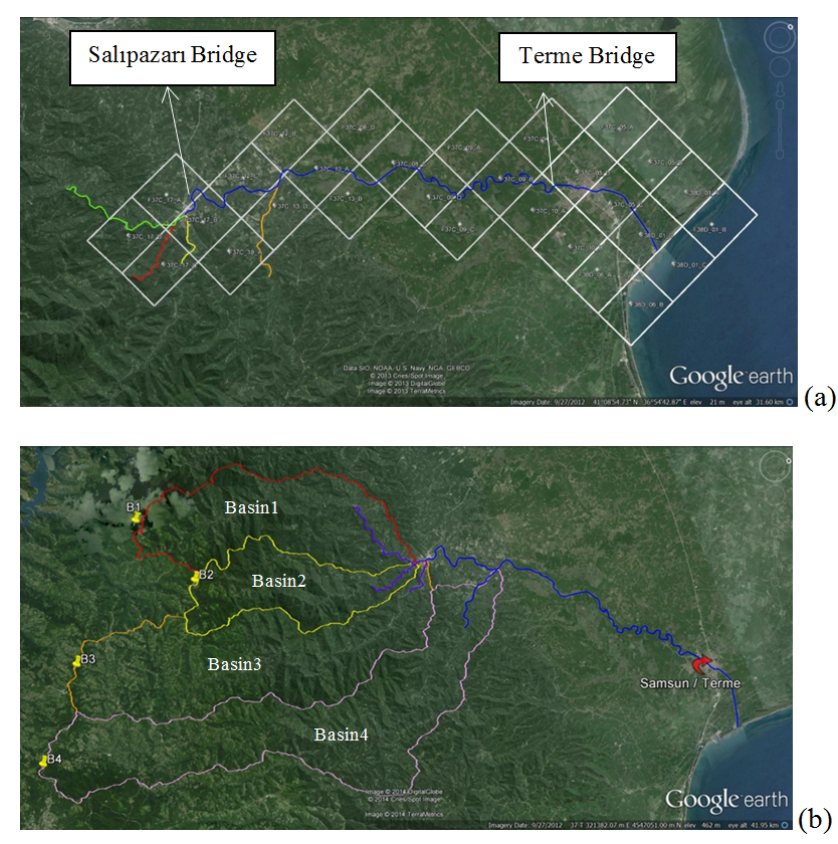

Figure 1. The river with upstream branches, $1 \times 5000^{-1}$ scaled orthophoto maps, location of two bridges (a) and the upstream sub basins (b).

In this study, hydraulic modelling works were conducted with Danish Hydraulic Institute (DHI) MIKE11 (one dimensional) (DHI, 2009) and MIKE21 (two dimensional) (DHI, 2010) models. The hydrographs having different return periods were obtained from a previous study in which classical statistical techniques were used to estimate the hydrographs at the discharge observation station (DSI2245) close to Sal1pazarıBridge. Hydrographs for the sub-basins were obtained by simple area-ratio based technique (Table 1). The location of the sub-basins are presented in Fig. 1b. The upstream precautions were analysed using the hydrographs for each sub-basin as different scenarios. The bed resistance $\left(1 \mathrm{n}^{-1}\right)$ is taken as 35 .

There is a dam project under construction at the downstream part of Basin 1. It is a multi-purpose dam for irrigation, water supply and flood control purposes. The reservoir volume of the dam at the normal water level $(134.00 \mathrm{~m})$ is $15.90 \mathrm{hm}^{3}$ and the volume at the maximum water level $(142.00 \mathrm{~m})$ is $23.31 \mathrm{hm}^{3}$. The $Q_{500}$ flood discharge 
Table 2. Scenario1 model results.

\begin{tabular}{lllll}
\hline Return period & $\begin{array}{l}\text { Input hydrograph } \\
\text { peak discharge (1) }\end{array}$ & $\begin{array}{l}\text { Output hydrograph } \\
\text { peak discharge (2) }\end{array}$ & $\begin{array}{l}\text { Peak discharge } \\
\text { difference (3)=(1)-(2) }\end{array}$ & $\begin{array}{l}\text { Percentage of } \\
\text { difference }(4)=(3) /(1)\end{array}$ \\
\hline $\mathrm{Q}_{25}$ & 578.27 & 472.60 & 105.67 & $\% 18$ \\
$\mathrm{Q}_{50}$ & 682.83 & 535.40 & 147.83 & $\% 22$ \\
$\mathrm{Q}_{100}$ & 792.41 & 573.40 & 219.01 & $\% 28$ \\
$\mathrm{Q}_{500}$ & 1041.34 & 619.00 & 422.34 & $\% 41$ \\
\hline
\end{tabular}

Table 3. Scenario 2 model results.

\begin{tabular}{|c|c|c|c|c|c|c|}
\hline \multirow[t]{2}{*}{ Return period } & \multicolumn{2}{|c|}{$\begin{array}{l}\text { Input hydrograph } \\
\text { peak discharge }\left(\mathrm{m}^{3} \mathrm{~s}^{-1}\right)\end{array}$} & \multicolumn{2}{|c|}{$\begin{array}{l}\text { Output hydrograph } \\
\text { peak discharge }\left(\mathrm{m}^{3} \mathrm{~s}^{-1}\right)\end{array}$} & \multirow[t]{2}{*}{$\begin{array}{l}\text { peak discharge difference } \\
\left(\mathrm{m}^{3} \mathrm{~s}^{-1}\right)(5)=(3)-(4)\end{array}$} & \multirow[t]{2}{*}{$\begin{array}{l}\text { Percentage of difference } \\
(6)=(5) /(3)\end{array}$} \\
\hline & (Terme B.) (1) & $(B \operatorname{asin} 4)(2)$ & $(\operatorname{Basin} 4)(3)$ & (City C.) (4) & & \\
\hline $\mathrm{Q}_{500}$ & 1041.34 & 603.33 & 1340.00 & 710.80 & 629.20 & $\% 47$ \\
\hline
\end{tabular}

brings $8,89 \mathrm{hm}^{3}$ water until the peak discharge $(14.5 \mathrm{~h})$ and $19.01 \mathrm{hm}^{3}$ to the reservoir area at the first $24 \mathrm{~h}$ of the hydrograph duration. The model studies for the $Q_{500}$ discharge were carried on with the reservoir volume consideration. It is assumed that both bottom outlet and the spillway operates when the water level of the reservoir is at $134.00 \mathrm{~m}$ and $Q_{500}$ flood occurs. The operation of the dam in flood condition was performed according to the stage-discharge relationship of the dam.

\section{Flood modelling}

The length of the stream is long in the study area, therefore it is preferred to use flexible mesh and the DTM of the study area (Fig. 2a) is converted into triangular mesh. One of the advantages of the flexible mesh is creating different size of elements for different parts of the maps. These different sizes of the elements give advantages for modelling (Fig. 2b).

The model scenarios were created for three different situations. The first one existing situation includes the today's conditions of the study area. The second one is about the application of SalipazariDam Project which is under final planning stage. The last one is hypothetical structures which are proposed as the structural management measures at the upstream of the basin.

The input hydrographs for different return periods to be used in these scenarios were obtained by using the observed discharge values at gauging station DSI2245 through statistical analyses. The input hydrographs are numbered as follows:

Hydrograph 1: these Hydrographs were obtained from discharge observations at gauge DSI2245 and represent the discharge contributions from Basin 1, Basin 2 and Basin3.

Hydrograph 2: the hydrographs for Basin 1 were obtained by using area-ratio method where discharge observations at gauge DSI2245 were used in the calculation.
Hydrograph 3: these Hydrographs for Basin2 were obtained by using area-ratio method where discharge observations at gauge DSI2245 were used in the calculation.

Hydrograph 4: these hydrographs for Basin3 were obtained by using area-ratio method where discharge observations at gauge DSI2245 were used in the calculation.

Hydrograph 5: these hydrographs for Basin 4 were obtained by using area-ratio method where discharge observations at gauge DSI2245 were used in the calculation.

Hydrograph 6: this model hydrograph includes summation of the $Q_{500}$ discharges of the Basin 2 and Basin 3. In addition, Basin 1 was included to the summation hydrograph with constant $62 \mathrm{~m}^{3} \mathrm{~s}^{-1}$ discharge and $Q_{500}$ spillway discharge. The hydrograph was prepared for the point of the SalıpazarıBridge (DSI2245). The aim of the hydrograph for model studies is simulating the situation when $Q_{500}$ flood discharge affecting the basins and Basin 1 is controlled by the SalıpazarıDam.

Hydrograph 7: this model hydrograph includes summation of the $Q_{500}$ discharges of the Basin 2 and constant $62 \mathrm{~m}^{3} \mathrm{~s}^{-1}$ discharges of Basin 3. In addition, Basin 1 was included in the hydrograph with constant $62 \mathrm{~m}^{3} \mathrm{~s}^{-1}$ discharge and $Q_{500}$ spillway discharge. The hydrograph was prepared for the point of the SalipazarıBridge (DSI2245). The aim of the hydrograph for model studies is simulating the situation when $Q_{500}$ flood discharge affecting the basins and Basin 2 is uncontrolled and remaining two basins have structures.

Hydrograph 8: this model hydrograph includes summation of the $Q_{500}$ discharges of the Basin 3 and constant $62 \mathrm{~m}^{3} \mathrm{~s}^{-1}$ discharges of Basin 2. In addition, Basin 1 was included in the hydrograph with constant $62 \mathrm{~m}^{3} \mathrm{~s}^{-1}$ discharge and $Q_{500}$ spillway discharge. The hydrograph is prepared for the point of the SalıpazarıBridge (DSI2245). The aim of the hydrograph for model studies is simulating the situation when $Q_{500}$ flood discharge affecting the basins and Basin 3 is uncontrolled and remaining two basins have struc- 
(a)

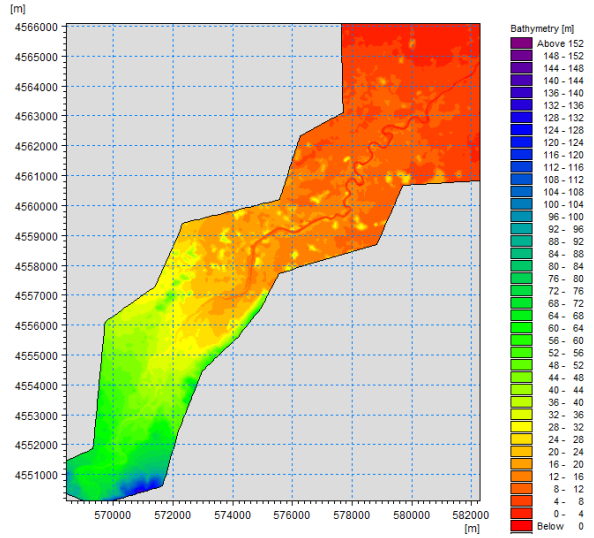

(b) Im

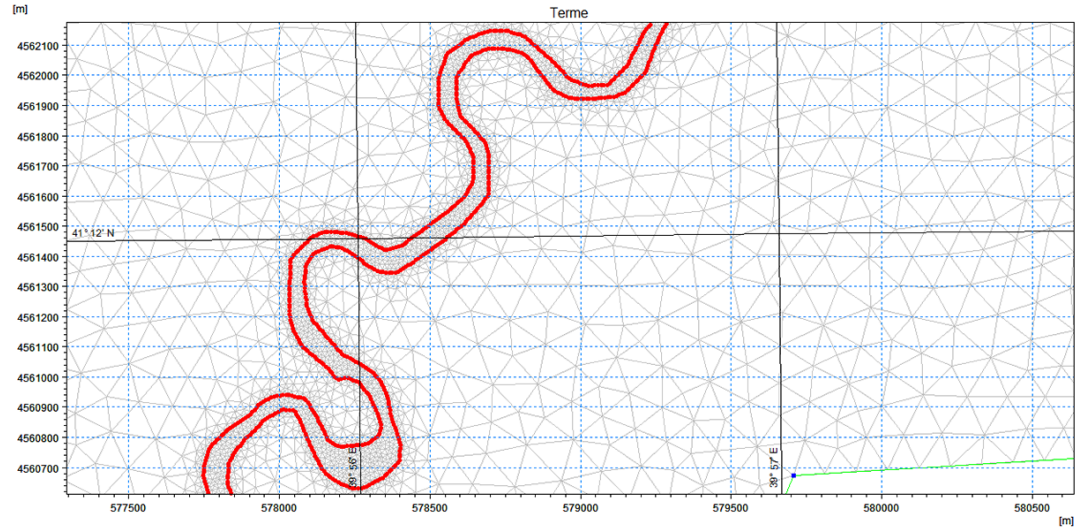

Figure 2. DTM (a) and flexible mesh (b) of the study area.

Table 4. Scenario3 model results.

\begin{tabular}{|c|c|c|c|c|c|c|}
\hline \multirow[t]{2}{*}{ Return period } & \multicolumn{2}{|c|}{$\begin{array}{l}\text { Input hydrograph } \\
\text { peak discharge }\left(\mathrm{m}^{3} \mathrm{~s}^{-1}\right)\end{array}$} & \multicolumn{2}{|c|}{$\begin{array}{l}\text { Output hydrograph } \\
\text { peak discharge }\left(\mathrm{m}^{3} \mathrm{~s}^{-1}\right)\end{array}$} & \multirow[t]{2}{*}{$\begin{array}{l}\text { peak discharge difference } \\
\left(\mathrm{m}^{3} \mathrm{~s}^{-1}\right)(5)=(3)-(4)\end{array}$} & \multirow[t]{2}{*}{$\begin{array}{l}\text { Percentage of difference } \\
(6)=(5) /(3)\end{array}$} \\
\hline & (Terme B.) (1) & $(\operatorname{Basin} 4)(2)$ & $(\operatorname{Basin} 4)(3)$ & (City C.) (4) & & \\
\hline $\mathrm{Q}_{500}$ & 790.23 & 603.33 & 1153.00 & 681.80 & 471.20 & $\% 41$ \\
\hline
\end{tabular}

tures. The bottom outlet discharge for SalıpazarıDam was obtained from the design reports as $62 \mathrm{~m}^{3} \mathrm{~s}^{-1}$ provided that the reservoir water level changes between the levels giving $62 \mathrm{~m}^{3} \mathrm{~s}^{-1}$ as the bottom outlet discharge. Since the spillway of the SalıpazarıDam was designed for the catastrophic flood discharge, $Q_{500}$ flood routing downstream values are relatively small. Peak discharge of the $Q_{500}$ after flood routing is $Q=27.18 \mathrm{~m}^{3} \mathrm{~s}^{-1}$.

\section{Results and discussions}

The upstream structural management measures were studied on scenario basis.

Scenario 1: the aim of the scenario is to see the input hydrograph peak discharge and output hydrograph peak discharge differences due to the meanders effect. The input point was selected as the Salipazari(DSI2245) and output point was selected as the Terme City centre (Terme Bridge) (Fig. 1a). The DSI report at the date of 11 July 2012 says; the flood event at the day of 9 July 2012 was measured as $990 \mathrm{~m}^{3} \mathrm{~s}^{-1}$ (DSI2245) and discharge was measured as $510 \mathrm{~m}^{3} \mathrm{~s}^{-1}$ at city centre.

This scenario represents the existing situation of the river and the basins. Table 2 gives the peak discharges of input and output hydrographs for different return periods and the percentage of difference in the input and output hydrograph peak values giving an information about the attenuation in the hydrographs due to meanderings.

The model results state that the meandering effect between SalıpazarıCity and the Terme City has a major role on the downstream stream discharge value. The routing capacity of the meanders at the study area can be seen from the discharge differences. Figure 3a shows that at some parts of the river water leaves the river bank and spreads over the open field. The river capacity at the Terme City centre is approximately $500 \mathrm{~m}^{3} \mathrm{~s}^{-1}$. Results show that if $Q_{50}$ passes through SalıpazarıBridge and Basin 4 does not participate the Terme River with any flood discharge, than river capacity will be approximately sufficient at Terme City.

Scenario 2: the aim of the study is to show the effect of Basin 4 contribution on the downstream hydrograph. The model studies were carried out only for $Q_{500}$ flood discharge which is used as the design discharge at the project studies. Hydrograph 1 was used as input hydrograph to represent . the Basin 1, 2 and 3. In addition to that, Hydrograph 5 was used as input to represent the Basin 4. Both of the Hydrographs reach the peak discharges at the same time individually. However, since the hydrograph input points are not the same, peak discharges do not overlap. Table 3 gives the peak discharges of input and output hydrographs for different return periods and the percentage of difference in the input and output hydrograph peak values.

The model results show that Basin 4 participation to the Terme River has a major effect on Terme City flood. Even if the peak discharges are not overlapping, Basin 4 has the highest $Q_{500}$ value compared to the other three basins. The meandering is effective after Basin 4 connection and peak discharges are not overlapping and peak discharges difference was calculated between Basin 4 connection and the Terme 
Table 5. Scenario4 model results.

\begin{tabular}{lllllll}
\hline Return period & $\begin{array}{l}\text { Input hydrograph } \\
\text { peak discharge }\left(\mathrm{m}^{3} \mathrm{~s}^{-1}\right)\end{array}$ & \multicolumn{2}{l}{$\begin{array}{l}\text { Output hydrograph } \\
\text { peak discharge }\left(\mathrm{m}^{3} \mathrm{~s}^{-1}\right)\end{array}$} & $\begin{array}{l}\text { peak discharge difference } \\
\left(\mathrm{m}^{3} \mathrm{~s}^{-1}\right)(5)=(3)-(4)\end{array}$ & $\begin{array}{l}\text { Percentage of difference } \\
(6)=(5) /(3)\end{array}$ \\
\cline { 2 - 5 } & (Terme B.) (1) & $($ Basin 4$)(2)$ & $($ Basin 4) $(3)$ & $($ City C. $)(4)$ & & \\
\hline Q500 & 62 & 603.33 & 658.23 & 527.4 & 130.83 & $\% 20$ \\
\hline
\end{tabular}

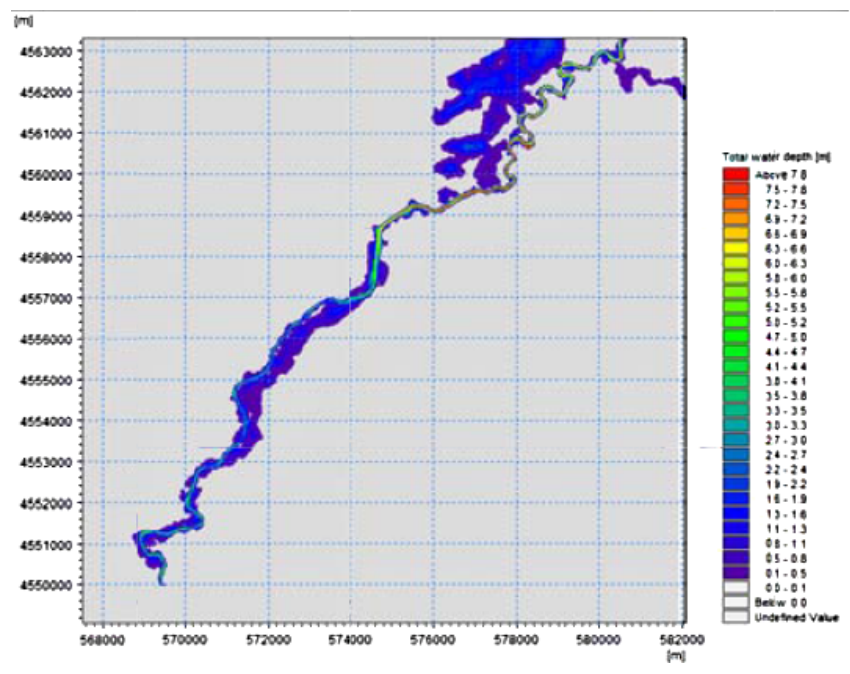

Figure 3. $Q_{500}$ flood water depth. (a) Scenario 1, (b) Scenario 2.

City and Fig. $3 \mathrm{~b}$ shows the water spreading out of the river bed after Basin 4 connection is massive.

Scenario 3: this scenario represents the SalipazarıDam project constructed situation. SalıpazarıDam project includes flood capacity so it has an effect on the Basin 1 output discharge. Since the studies were based on the interim project of the dam, these models can be called as projected situation. Since the location of SalipazariDam is at the downstream part of Basin 1, hydrological studies were changed only for Basin1. The other Basins were remained the same with existing situation. The model studies were carried on for $Q_{500}$ flood discharge situation. The new hydrograph includes the value of $62 \mathrm{~m}^{3} \mathrm{~s}^{-1}$ constant bottom outlet and the $Q_{500}$ spillway design discharge.

Hydrograph 6 was used as input hydrograph to represent the Basin 1, Basin 2 and Basin 3. Addition to that, Hydrograph 5 was used as input to represent the Basin 4. Both of the Hydrographs reach the peak discharges at the same time individually. However, since the hydrograph input points are not the same, peak discharges do not overlap. Table 4 gives the peak discharges of input and output hydrographs for different return periods and the percentage of difference in the input and output hydrograph peak values

The model result shows that even if the SalipazariDam is constructed with the planed flood capacity, it is not sufficient for the Terme City safety for the condition of the whole basins are affected from the flood at the same time.

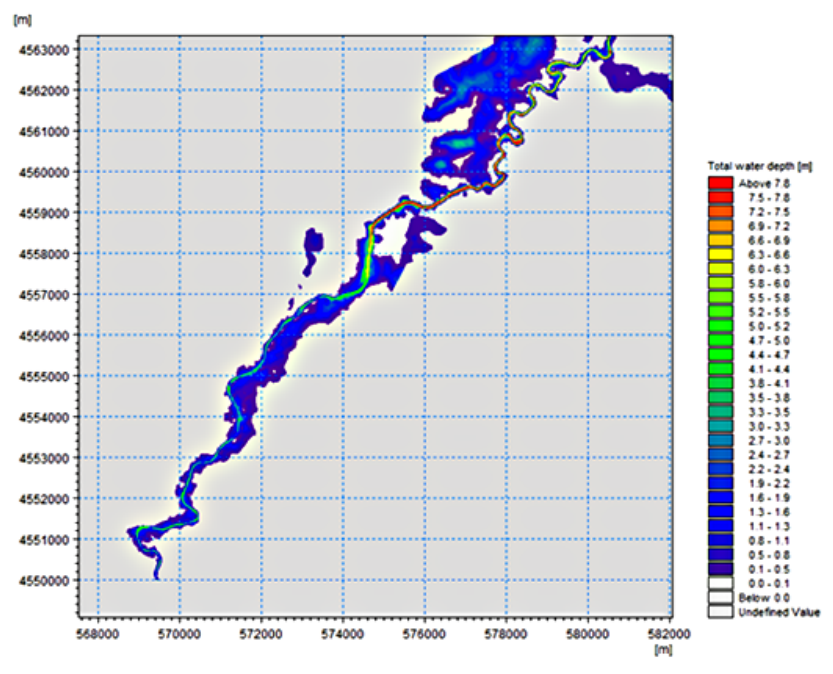

Scenario 4: this scenario represents the SalipazariDam design project constructed situation and possible future projects for remaining sub-basins. Since the Scenario 3 shows that the SalıpazarıDam flood capacity is not sufficient at the time of the other three sub-basins are also affected from the flood, the aim of this scenario is controlling the whole flood discharges of the Basin 2 and 3 in addition to SalıpazarıDam flood capacity for model calculations.

This scenario represents the possible solutions at the basins for the upstream part of the SalıpazarıCity. Basin 1 could be controlled with SalipazarıDam and only bottom outlet discharge $\left(62 \mathrm{~m}^{3} \mathrm{~s}^{-1}\right)$ is included in the model. The assumption of this scenario is controlling the whole $Q 500$ flood capacity of the Basin 2 and 3 with upstream hypostatical reservoir structures which means Basin 2 and 3 have no effect with their discharges. Controlled discharges from these basins are considered, and the Basin 4 contribution remains the same with existing situation.

The model studies were carried on for $Q_{500}$ flood discharge situation. Since the Basin 4 contribution remains the same with the existing situation, the hydrograph of Basin 4 was used directly. The remaining basins were represented with a constant bottom outlet $62 \mathrm{~m}^{3} \mathrm{~s}^{-1}$ in the model. Table 5 gives the peak discharges of input and output hydrographs for different return periods and the percentage of difference in the input and output hydrograph peak values 
Table 6. Scenario5 model results.

\begin{tabular}{|c|c|c|c|c|c|c|}
\hline \multirow[t]{2}{*}{ Return period } & \multicolumn{2}{|c|}{$\begin{array}{l}\text { Input hydrograph } \\
\text { peak discharge }\left(\mathrm{m}^{3} \mathrm{~s}^{-1}\right)\end{array}$} & \multicolumn{2}{|c|}{$\begin{array}{l}\text { Output hydrograph } \\
\text { peak discharge }\left(\mathrm{m}^{3} \mathrm{~s}^{-1}\right)\end{array}$} & \multirow[t]{2}{*}{$\begin{array}{l}\text { peak discharge difference } \\
\left(\mathrm{m}^{3} \mathrm{~s}^{-1}\right)(5)=(3)-(4)\end{array}$} & \multirow[t]{2}{*}{$\begin{array}{l}\text { Percentage of difference } \\
(6)=(5) /(3)\end{array}$} \\
\hline & (Terme B.) (1) & $(\operatorname{Basin} 4)(2)$ & $(\operatorname{Basin} 4)(3)$ & (City C.) (4) & & \\
\hline
\end{tabular}

The model results show that if upstream precautions are applied before the SalıpazarıBridge, the $Q_{500}$ flood discharge from Basin 4 can pass from the Terme city centre safely.

Scenario 5: this scenario represents the SalıpazarıDam Design project constructed situation and possible future projects for remaining basins. The Scenario 4 model results show that $Q_{500}$ flood discharge of the Basin 4, individually fulfils the Terme City river capacity. The structural solutions for two of the remaining three basins were considered in this scenario. The selection of control structures for Basin 2, 3 and 4 includes complex design procedures. Therefore simple assumption is made for this scenario. All basins have similar characteristics. The control structures' properties were assumed to be the same with that basis and SalıpazariDam behaviour at flood situation applied to the other three basins for flood control purposes. This scenario assumes each basin brings $62 \mathrm{~m}^{3} \mathrm{~s}^{-1}$ at the time of flood event. New possible future flood protection designs on Basin 2, 3 and 4 will have full flood capacity for $Q_{500}$ discharge means the scenario assumption brings the study at safe side.

This scenario represents the possible upstream solutions for Basin 2, Basin 3 and 4. The base hydrological input for this scenario is Basin 1 controlling with SalıpazarıDam. In addition to that two of the three basins are controlled. So that only one basin remains uncontrolled. The study also aims to show which basin has important role for flood condition. Table 6 gives the peak discharges of input and output hydrographs for different return periods and the percentage of difference in the input and output hydrograph peak values.

\section{Conclusions}

In total, five different scenarios were studied for four upstream sub-basins. The existing circumstance of the Terme River states that the meanders of the river have a major effect on the flood situation. The discharge measurements between SalıpazarıBridge and the Terme Bridge have approximately $35 \%$ reduction of the peak discharge. The model studies with and without Basin 4 state that, Basin 4 has the important role on the Terme City flood. The flood discharge of the Basin 4 is higher than the other three basins' flood discharges. Since the Basin 4 connection is closer to the urbanized area, risk factor is increasing. SalıpazariDam flood capacity is not sufficient individually to protect Terme City against flooding. However other basins do not have any flood protection structures yet and additional control structures would also be needed for other sub-basins.

All model studies were based on the assumption of the peak discharges overlapping at basins. The hydrological model has an important role on flood modelling studies. Well calibrated hydrological model is needed to be used in calculations of the model input discharges with rainfall-runoff relation. Early warning systems for the sub-basins can be also considered since the flood peak discharge reaches from Sal1pazarıBridge to the Terme City approximately in $4 \mathrm{~h}$.

Acknowledgements. The authors thank DSI staff for providing the data and support during this study.

\section{References}

Danish Hydraulic Institute, MIKE 11 reference manual, Appendix A, Scientific background, Danish Hydraulic Institute, Hørsholm, Denmark, 417-500, 2009.

Danish Hydraulic Institute. MIKE 21 FM HD Reference manual, Danish Hydraulic Institute, Hørsholm, Denmark, 11-152, 2010.

Hooijer, A., Klijn, F., Pedroli, G. B. M., and Van Os, A. G.: Towards sustainable flood risk management in the Rhine and Meuse river basins: Synopsis of the findings of IRMA-SPONGE, River Res. Appl., 20, 343-357, 2004.

de Moel, H., van Alphen, J., and Aerts, J. C. J. H.: Flood maps in Europe - methods, availability and use, Nat. Hazards Earth Syst. Sci., 9, 289-301, doi:10.5194/nhess-9-289-2009, 2009.

Petrow, T., Thieken, A. H., Kreibich, H., Bahlburg, C. H., and Merz, B.: Improvements on flood alleviation in Germany: Lessons learned from the Elbe flood in August 2002, Environ. Manage., 38, 717-732, 2006.

Şahin, E., Akıntuğ, B., and Yanmaz, A. M.: Modeling of Morphou (Güzelyurt) Flood and Remedial Measures, Teknik Dergi, 24, 6447-6462, 2013.

Van Alphen, J. and van Beek, E.: From flood defence to flood management Prerequisites for sustainable flood management, in: Floods, from Defence to Management, edited by: van Alphen, J., van Beek, E., and Taal, M., Taylor and Francis Group, London, 325-346, 2006. 